\title{
Cinacalcet Treatment for Secondary Hyperparathyroidism in Dialysis Patients: An Observational Study in Routine Clinical Practice
}

\author{
Jordi Bover ${ }^{a} \quad$ Rafael Pére $^{b} \quad$ Manuel Molina ${ }^{c}$ Beatriz Benavides ${ }^{d}$ \\ Francisco Ariza $^{\mathrm{e}}$ José Luis Miguel ${ }^{\mathrm{f}}$ Fernando Tornero $^{\mathrm{g}}$ \\ Josep Vicens Torregrosah ${ }^{h}$ on behalf of the Renal Osteodystrophy Group of the \\ Spanish Society of Nephrology and all the investigators from the REHISET study

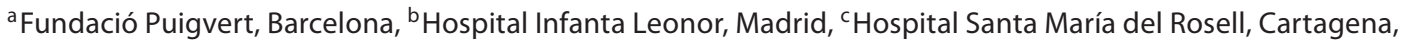 \\ ${ }^{\mathrm{d} H o s p i t a l}$ Universitario Puerto Real, Cádiz, ${ }^{\mathrm{e}}$ Hospital Reina Sofía, Córdoba, ${ }^{\mathrm{f}} \mathrm{Hospital}$ La Paz, Madrid,

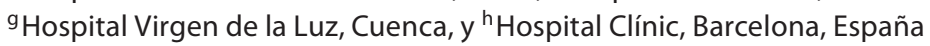

\section{Key Words}

Calcimimetic $\cdot$ Cinacalcet $\cdot$ Secondary

hyperparathyroidism $\cdot$ Dialysis $\cdot$ Parathyroid hormone $\cdot$

Calcium $\cdot$ Phosphorus

\begin{abstract}
Background: Cinacalcet reduces intact parathyroid hormone (iPTH), Ca and P serum levels in patients with secondary hyperparathyroidism (SHPT). Methods: This Spanish, multicenter, observational, retrospective study collected data from SHPT dialysis patients 12 weeks before and up to 72 weeks after starting cinacalcet in clinical practice. $\boldsymbol{R} \boldsymbol{e}$ sults: Data from 428 patients with uncontrolled SHPT despite receiving standard of care $(29 \%$ with baseline iPTH $501-800 \mathrm{pg} / \mathrm{ml} ; 51 \%$ with $>800 \mathrm{pg} / \mathrm{ml}$ ) were collected. Percentages of patients within National Kidney Foundation Kidney Disease Outcomes Quality Initiative targets at baseline and 72 weeks were: iPTH, 0 versus $32.5 \%$ ( $p<0.05$ ); Ca, 40.1 versus $50 \%(p<0.05) ; P, 47.7$ versus $53.8 \%(p=0.162)$. Vitamin D sterol use decreased from $53.3 \%$ at baseline to $36.7 \%$ at 72
\end{abstract}

weeks $(p<0.05)$. The mean \pm SD cinacalcet dose at 72 weeks was $44.0 \pm 25.8,51.7 \pm 31.3$ and $57.1 \pm 37.0 \mathrm{mg}$ for patients with baseline iPTH 301-500, 501-800 or $>800$ pg/ml, respectively. The main adverse reactions were nausea (5.4\%), dyspepsia (5.1\%) and vomiting (3.7\%). Conclusions: The introduction of cinacalcet improved the routine clinical management of SHPT in a large cohort of Spanish dialysis patients. Cinacalcet is effective and well tolerated regardless of disease severity, and maintains its efficacy over 72 weeks.

Copyright $\odot 2010$ S. Karger AG, Basel

\section{Introduction}

Secondary hyperparathyroidism (SHPT) is a progressive disease associated with chronic kidney disease and characterized by elevated parathyroid hormone (PTH) levels and disordered mineral metabolism $[1,2]$.

Elevated serum PTH, P and Ca levels are independently associated with increased morbidity and mortality in dialyzed patients [3]. In their clinical practice guidelines

Dr. Josep Vicens Torregrosa

Villarroel, 170

ES-08036 Barcelona (Spain)

Tel. +34 932275 423, Fax +34 932275498

E-Mail karger@karger.ch Accessible online at:

www.karger.com www.karger.com/nec 
the National Kidney Foundation Kidney Disease Outcomes Quality Initiative (NKF KDOQI ${ }^{\mathrm{TM}}$ ) [4] established treatment goals for mineral metabolism to improve dialysis patient care.

Hypercalcemia and hyperphosphatemia, as a result of either SHPT or the use of therapeutic agents, contribute to soft-tissue and vascular calcification, which might increase cardiovascular disease and mortality [5]. For these reasons, new therapeutic alternatives should be envisaged in order to reduce the risks associated with the adverse effects of traditional therapies.

The calcimimetic cinacalcet mainly increases the sensitivity of the Ca-sensing receptor to extracellular $\mathrm{Ca}$ [6], thus inhibiting the release of PTH [7], although, as recently shown, it also decreases PTH synthesis [8]. Calcimimetic agents and vitamin $\mathrm{D}$ sterols have a different mechanism of action, which not only decreases PTH synthesis but also has indirect effects that limit their efficacy (increase in intestinal $\mathrm{Ca}$ and $\mathrm{P}$ absorption and low bone turnover). Phase III clinical trials have shown that treatment of SHPT with cinacalcet simultaneously reduces $\mathrm{PTH}, \mathrm{Ca}, \mathrm{P}$ and $\mathrm{Ca} \times \mathrm{P}$ levels, allowing more patients to achieve KDOQI ${ }^{\mathrm{TM}}$ treatment targets $[9,10]$. However, data about the effectiveness of cinacalcet in routine clinical practice are scarce $[11,12]$. REHISET is a Spanish observational multicenter study intended to describe the efficacy and safety results of cinacalcet in the treatment of SHPT in a large cohort of dialysis patients in routine clinical practice and compare its results with published clinical trials.

\section{Material and Methods}

This Spanish, multicenter, observational, retrospective study was designed to collect data from dialysis patients treated de novo with cinacalcet drug after its commercialization in Spain in June 2005. Centers were distributed uniformly throughout all the Spanish regions. Main inclusion criteria were: patients who had received dialysis for $>30$ days before initiation of cinacalcet, aged $\geq 18$ years, diagnosed with SHPT, with laboratory data from 12 weeks before and up to 72 weeks after starting cinacalcet treatment in routine clinical practice and with at least 16 weeks of follow-up with cinacalcet treatment. Patients were excluded if they had been included in a clinical trial of cinacalcet during the follow-up period. The study protocol was approved by all Ethics Committees of centers where it was required according to legislation on retrospective observational studies. All recruited patients started cinacalcet between June 2005 and March 2006. The day of cinacalcet initiation was considered as the baseline time point (week 0). Cinacalcet and other treatment modifications during the time of the study were performed according to the protocol of each center (in accordance with KDOQI treatment recommenda- tions [4], which were the most accepted and best known by Spanish physicians until the recent publication of the recommendations of the Spanish Society of Nephrology (SEN) [13] and the new Kidney Disease: Improving Global Outcomes (KDIGO) guidelines [14]). Relevant medical history, comorbidities, and laboratory data were collected and assigned (according to date of extraction) to study time points at weeks $-12 \pm 2$ weeks, $-4 \pm 2,0$, $+4 \pm 2,+12 \pm 2,+16 \pm 2,+24 \pm 4,+48 \pm 4$ and $+72 \pm 4$. Onsite monitoring was conducted in all centers to ensure quality of data. The primary endpoint was the percentage of cinacalcettreated patients within KDOQI target for intact PTH (iPTH). Secondary endpoints included the percentage of patients within KDOQI targets for $\mathrm{Ca}$ and $\mathrm{P}$, the changes in biochemical parameters (iPTH, Ca and $\mathrm{P}$ ) during the study, the changes in cinacalcet utilization, the usage of vitamin D analogs and phosphate binders, and the safety profile of cinacalcet.

\section{Statistical Analysis}

Summary statistics were calculated for continuous and categorical variables. Analyses were based on observed data only. The McNemar test was applied to compare frequencies between different time points (matched-pairs analysis). Differences in mean levels between subgroups or with respect to baseline were assessed using Student's t tests or paired t tests, respectively. The effect of cinacalcet on iPTH, P and Ca with respect to disease severity was explored by calculating $95 \%$ confidence intervals for these parameters at each study point in 3 patient subgroups (defined according to their baseline iPTH): $301-500 \mathrm{pg} / \mathrm{ml}(31.9-53 \mathrm{pmol} / \mathrm{l})$; $501-800 \mathrm{pg} / \mathrm{ml}(53.1-84.8 \mathrm{pmol} / \mathrm{l})$ and $>800 \mathrm{pg} / \mathrm{ml}(>84.8 \mathrm{pmol} / \mathrm{l})$. These cut-offs were chosen according to the upper iPTH limit in the KDIGO guidelines [14] (300 pg/ml), the upper limit for a significant increase in mortality in SEN recommendations [13] (500 $\mathrm{pg} / \mathrm{ml}$ ), and the cut-off value for considering parathyroidectomy in KDOQI guidelines [4] $(800 \mathrm{pg} / \mathrm{ml})$. All the calculations were performed using SPSS ${ }^{\circledR} 14.0$ (SPSS Inc., Chicago, Ill., USA).

\section{Results}

\section{Patients}

The study included 428 patients initiating cinacalcet in the clinical practice (baseline time point), from whom 150 did not complete the follow-up. Data were collected from 36 hospital nephrology services or satellite dialysis units. Figure 1 shows the data availability at each study point, based on primary endpoints, and the reasons for patient withdrawals. Forty-six patients $(10.8 \%)$ were lost to follow-up during the study period (of whom 34 belonged to two centers that did not collect data after 24 weeks due to logistic problems). There were 25 deaths (5.8\%) during the follow-up, none of them related to cinacalcet treatment: 15 patients (60\%) died due to cardiovascular causes, 8 patients (32\%), due to noncardiovascular causes, and in 2 patients (8\%) we were not able to document the cause of death. 


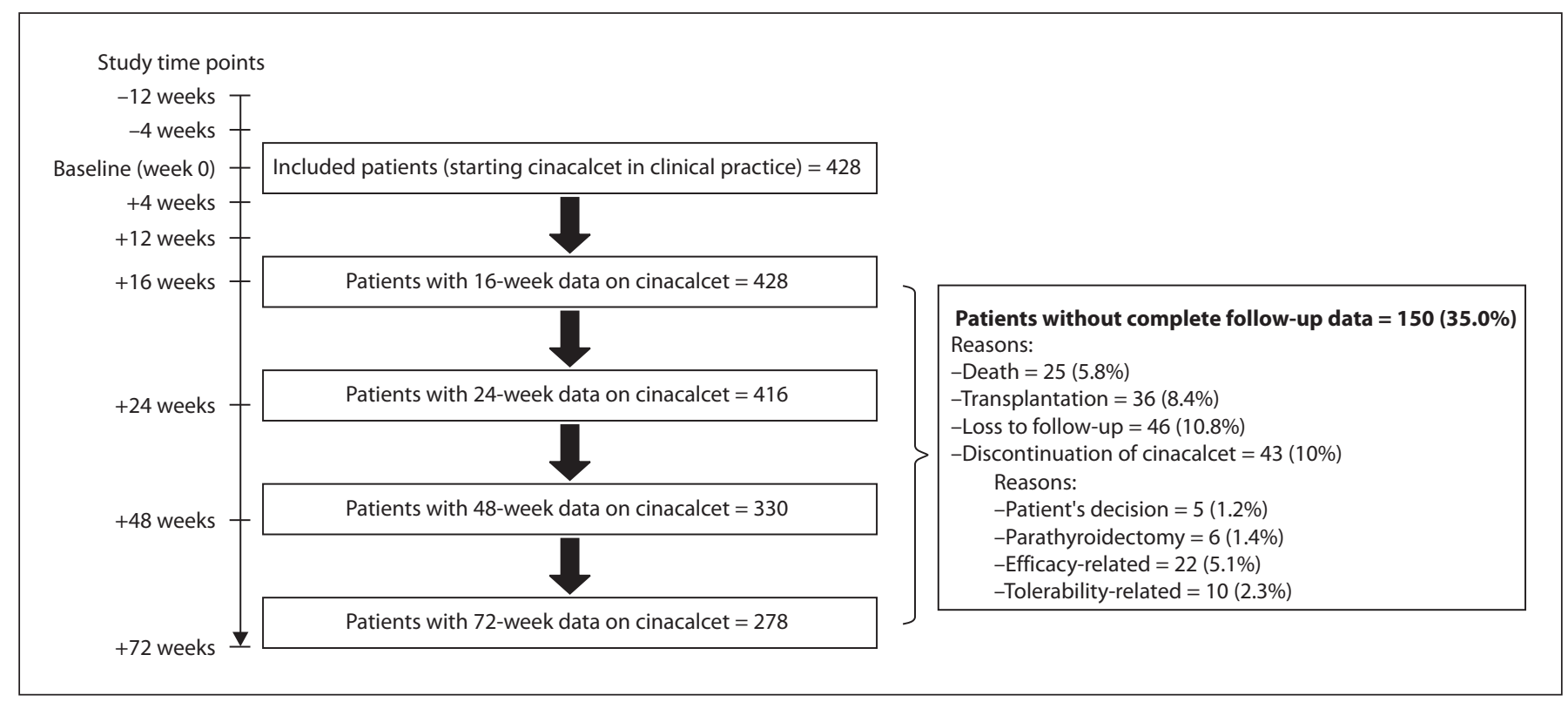

Fig. 1. Patients with data available at each study point and reasons for incomplete follow-up data.

Table 1. Baseline characteristics of 428 dialysis patients starting cinacalcet in clinical practice

\begin{tabular}{lc}
\hline Baseline characteristics & Patients \\
\hline Age, years & \\
Mean \pm SD & $60.2 \pm 15.7$ \\
Range & $19-92$ \\
Men, $\mathrm{n}$ & $232(54.2 \%)$ \\
Diabetes, $\mathrm{n}$ & $78(18.2 \%)$ \\
Time on dialysis & \\
Median, months & 57.6 \\
Q1-Q3, months & $28.2-119.1$ \\
Prior parathyroidectomy, $\mathrm{n}$ & $24(5.6 \%)$ \\
Previous transplantation, $\mathrm{n}$ & $109(25.5 \%)$ \\
1 & $73(17.1 \%)$ \\
2 or $>2$ & $36(8.4 \%)$ \\
Etiology of renal disease & \\
Diabetic nephropathy, $\mathrm{n}$ & $42(9.8 \%)$ \\
Glomerulonephritis, $\mathrm{n}$ & $78(18.2 \%)$ \\
Vascular nephropathy, $\mathrm{n}$ & $49(11.4 \%)$ \\
Polycystic kidney disease & $32(7.5 \%)$ \\
Chronic pyelonephritis, $\mathrm{n}$ & $60(14.0 \%)$ \\
Hereditary, $\mathrm{n}$ & $12(2.8 \%)$ \\
Other, $\mathrm{n}$ & $55(12.9 \%)$ \\
Unknown, $\mathrm{n}$ & $100(23.4 \%)$ \\
Dialysis type & \\
Hemodialysis, $\mathrm{n}$ & $379(88.6 \%)$ \\
Hemodiafiltration, $\mathrm{n}$ & $35(8.2 \%)$ \\
Long nocturnal HD, $\mathrm{n}$ & $1(0.2 \%)$ \\
Peritoneal dialysis, $\mathrm{n}$ & $13(3.0 \%)$ \\
\hline
\end{tabular}

\section{Patient Characteristics at Cinacalcet Initiation}

Patient characteristics at initiation of cinacalcet are summarized in table 1 . Mean $\pm \mathrm{SD}$ age was $60.2 \pm 15.7$ years, $54.2 \%$ were men, and most of them were undergoing hemodialysis (97\%). Mean PTH, Ca and P at baseline were $941 \pm 516 \mathrm{pg} / \mathrm{ml}(99.7 \pm 54.7) \mathrm{pmol} / \mathrm{l}), 9.6 \pm 0.8$ $\mathrm{mg} / \mathrm{dl}(2.4 \pm 0.2 \mathrm{mmol} / \mathrm{l})$ and $5.6 \pm 1.4 \mathrm{mg} / \mathrm{dl}(1.8 \pm 0.4$ $\mathrm{mmol} / \mathrm{l})$, respectively. Before the initiation of cinacalcet, $80 \%$ of patients had moderate or severe SHPT (29\% with baseline iPTH 501-800 pg/ml and 51\% with $>800 \mathrm{pg} / \mathrm{ml}$ ), despite receiving standard care previously, i.e. vitamin $\mathrm{D}$ sterols (53.3\% of patients) and phosphate binders (93\%) (table 2).

The iPTH levels in the 12 weeks before the initiation of cinacalcet increased from $812 \pm 510 \mathrm{pg} / \mathrm{ml}(86.1 \pm$ $54.1 \mathrm{pmol} / \mathrm{l}$ ) to $941 \pm 516 \mathrm{pg} / \mathrm{ml}$ at baseline (median percentage change of $+18.8 \pm 201.8 \%$ ) whereas the $\mathrm{Ca}$ and $\mathrm{P}$ levels remained unchanged, i.e. levels of $9.8 \pm 0.9 \mathrm{mg} / \mathrm{dl}$ $(2.4 \pm 0.2 \mathrm{mmol} / \mathrm{l})$ and $5.6 \pm 1.6 \mathrm{mg} / \mathrm{dl}(1.8 \pm 5.2$ $\mathrm{mmol} / \mathrm{l}$ ) at week -12 , respectively, with median changes of $-1.6 \pm 8.1$ and $0 \pm 34.0 \%$.

The mean albumin levels were $3.9 \pm 0.4 \mathrm{~g} / \mathrm{dl}$, and remained unchanged during the follow-up $(3.8 \pm 0.4 \mathrm{~g} / \mathrm{dl}$ at week 72). Mean dialysate $\mathrm{Ca}$ concentration at baseline was $2.8 \pm 0.3 \mathrm{mEq} / \mathrm{l}$ (without changes at week 72: $2.9 \pm$ $0.3 \mathrm{mEq} / \mathrm{l})$. 
Table 2. Medications for SHPT (including cinacalcet) administered at each study point

\begin{tabular}{|c|c|c|c|}
\hline & Baseline $(n=428)$ & Week $24(n=416)$ & Week $72(\mathrm{n}=278)$ \\
\hline \multicolumn{4}{|l|}{ Cinacalcet } \\
\hline Patients, $\mathrm{n}$ & $428(100 \%)$ & $416(100 \%)$ & $278(100 \%)$ \\
\hline Mean dose $( \pm S D), \mathrm{mg} /$ day & $28.9 \pm 6.0$ & $45.9 \pm 26.5^{*}$ & $52.3 \pm 33.8^{*}$ \\
\hline Median dose, mg/day & 30 & 30 & 45 \\
\hline \multicolumn{4}{|l|}{ Vitamin D sterols ${ }^{1}$} \\
\hline Patients, $\mathrm{n}$ & $228(53.3 \%)$ & $185(44.5 \%)^{*, 2}$ & $102(36.7 \%)^{*, 3}$ \\
\hline \multicolumn{4}{|l|}{ Oral calcitriol } \\
\hline Patients, $\mathrm{n}$ & $45(10.5 \%)$ & $37(8.9 \%)$ & $17(6.1 \%)$ \\
\hline Mean dose $( \pm S D), \mu g /$ week & $1.83 \pm 0.9$ & $1.94 \pm 1.14$ & $1.36 \pm 0.6^{*}$ \\
\hline Median dose, $\mu \mathrm{g} /$ week & 1.5 & 1.5 & 1.5 \\
\hline \multicolumn{4}{|l|}{ Intravenous calcitriol } \\
\hline Patients, $\mathrm{n}$ & $58(13.6 \%)$ & $30(7.2 \%)^{*}$ & $11(4.0 \%)^{*}$ \\
\hline Mean dose $( \pm S D), \mu g /$ week & $2.6 \pm 1.9$ & $2.1 \pm 1.2^{*}$ & $2.0 \pm 1.0^{*}$ \\
\hline Median dose, $\mu \mathrm{g} /$ week & 2.0 & 2.0 & 2.0 \\
\hline \multicolumn{4}{|l|}{ Intravenous alfacalcidiol } \\
\hline Patients, $\mathrm{n}$ & $47(11.0 \%)$ & $44(10.6 \%)$ & $20(7.2 \%)$ \\
\hline Mean dose $( \pm S D), \mu g /$ week & $4.3 \pm 2.1$ & $4.8 \pm 2.5^{*}$ & $3.6 \pm 1.8^{*}$ \\
\hline Median dose, $\mu \mathrm{g} /$ week & 4.0 & 4.5 & 3.0 \\
\hline \multicolumn{4}{|l|}{ Intravenous paricalcitol } \\
\hline Patients, $\mathrm{n}$ & $86(20.1 \%)$ & $78(18.8 \%)$ & $53(19.1 \%)$ \\
\hline Mean dose $( \pm \mathrm{SD}), \mu \mathrm{g} /$ week & $10.6 \pm 4.9$ & $10.8 \pm 6.1$ & $9.6 \pm 6.6^{*}$ \\
\hline Median dose, $\mu \mathrm{g} /$ week & 10 & 9 & 9 \\
\hline \multicolumn{4}{|l|}{ Phosphate binders ${ }^{4}$} \\
\hline Patients, $\mathrm{n}$ & $398(93.0 \%)^{5}$ & $370(88.9 \%)^{6}$ & $248(89.2 \%)^{7}$ \\
\hline \multicolumn{4}{|l|}{ Calcium-based } \\
\hline Patients, $\mathrm{n}$ & $193(45.1 \%)$ & $239(57.5 \%)^{*}$ & $151(54.3 \%)^{*}$ \\
\hline Mean dose $( \pm S D), \mathrm{mg} /$ day & $2,379 \pm 3,699$ & $2,500 \pm 3,416$ & $2,195 \pm 3,900$ \\
\hline Median dose, mg/day & 1,500 & 2,000 & 1,500 \\
\hline \multicolumn{4}{|l|}{ Sevelamer } \\
\hline Patients, $\mathrm{n}$ & $326(76.2 \%)$ & $285(68.5 \%)$ & $205(73.7 \%)$ \\
\hline Mean dose $( \pm S D), \mathrm{mg} /$ day & $5,377 \pm 2,579$ & $5,046 \pm 2,610$ & $4,975 \pm 2,476^{*}$ \\
\hline Median dose, mg/day & 4,800 & 4,800 & 4,800 \\
\hline \multicolumn{4}{|c|}{ Aluminum-based (acetate/carbonate) } \\
\hline Patients, $\mathrm{n}$ & $84(19.6 \%)$ & $57(13.7 \%)$ & $31(11.2 \%)^{*}$ \\
\hline Mean dose $( \pm S D), \mathrm{mg} /$ day & $1,347 \pm 806$ & $1,253 \pm 587$ & $1,267 \pm 713$ \\
\hline Median dose, $\mathrm{mg} /$ day & 1,165 & 1,165 & 932 \\
\hline \multicolumn{2}{|c|}{$\begin{array}{l}{ }^{*} \mathrm{p}<0.05 \text { vs. baseline. } \\
{ }^{1} \text { Eight, } 5 \text { and } 1 \text { patients were treated with } 2 \text { vitamin D/ana- } \\
\text { logues at baseline, week } 24 \text { and week } 72 \text {, respectively; } 55 \text { patients } \\
\text { (12.9\%) never used vitamin D analogues during the whole study. } \\
{ }^{2} \text { One patient was receiving oral paricalcitol and } 1 \text { patient cho- } \\
\text { lecalciferol. }\end{array}$} & $\begin{array}{l}\text { patients were treated with } 3 \text { ph } \\
24 \text { and week } 72 \text {, respectively; } 6 \\
\text { phate binders during the whole } \\
5 \text { One patient was receiving } \\
\text { carbonate and } 1 \text { patient sucralf } \\
6 \text { Two patients were receivin } \\
\text { carbonate and } 1 \text { patient sucralf } \\
{ }^{7} \text { One patient was receiving } \\
\text { carbonate and } 2 \text { patients were }\end{array}$ & $\begin{array}{l}\text { nders at baseline, week } \\
1.4 \% \text { never used phos- } \\
\text { glucobionate + calcium } \\
\text { glucobionate + calcium } \\
\text { glucobionate + calcium } \\
\text { ucralfate + magaldrate. }\end{array}$ \\
\hline
\end{tabular}



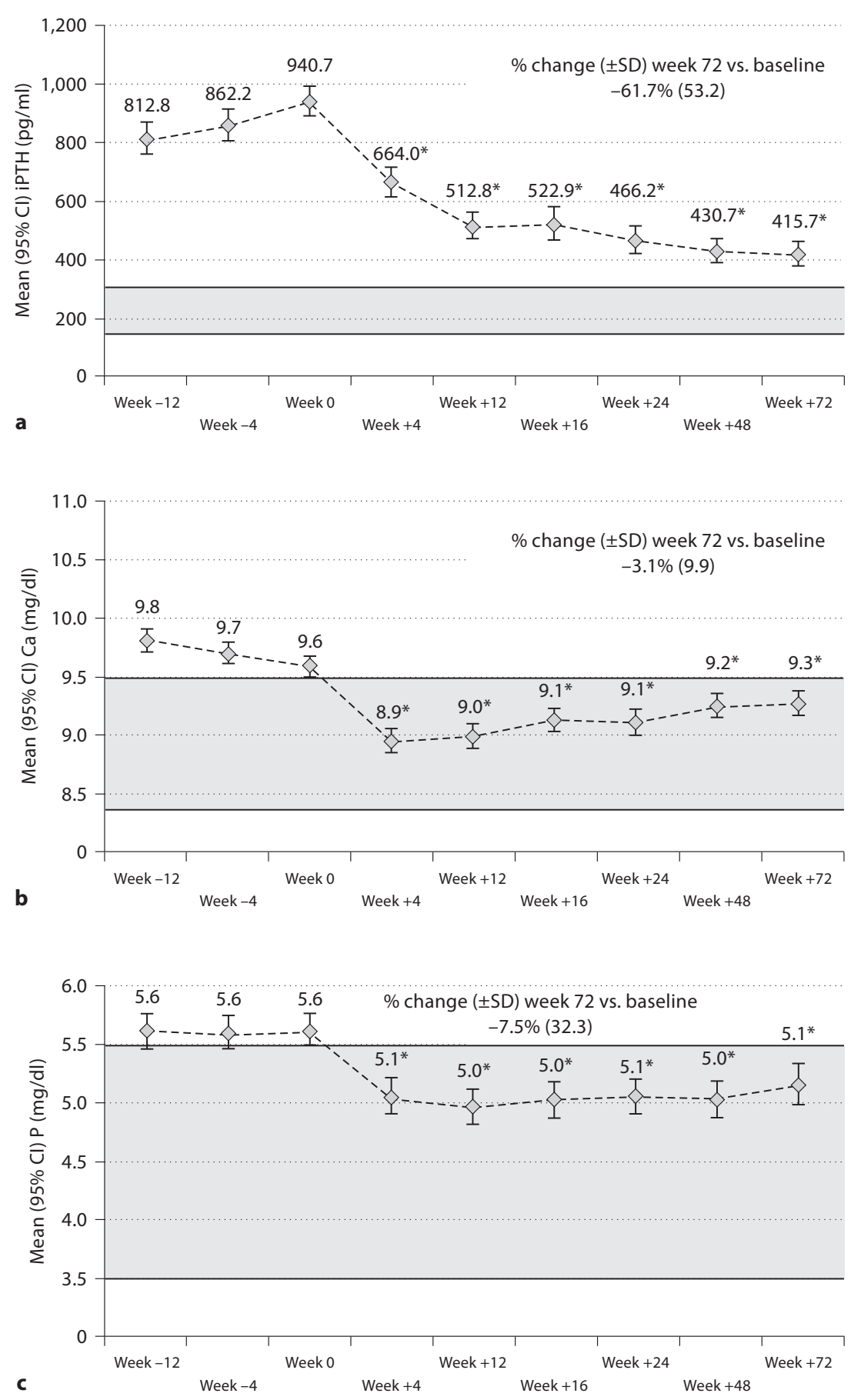

Fig. 2. Evolution of mineral metabolism parameters during the study in the overall sample. ${ }^{*} \mathrm{p}<0.05$ versus week 0 (baseline); \% change is expressed as median percentage of change. Gray area $=$ KDOQI targets. 

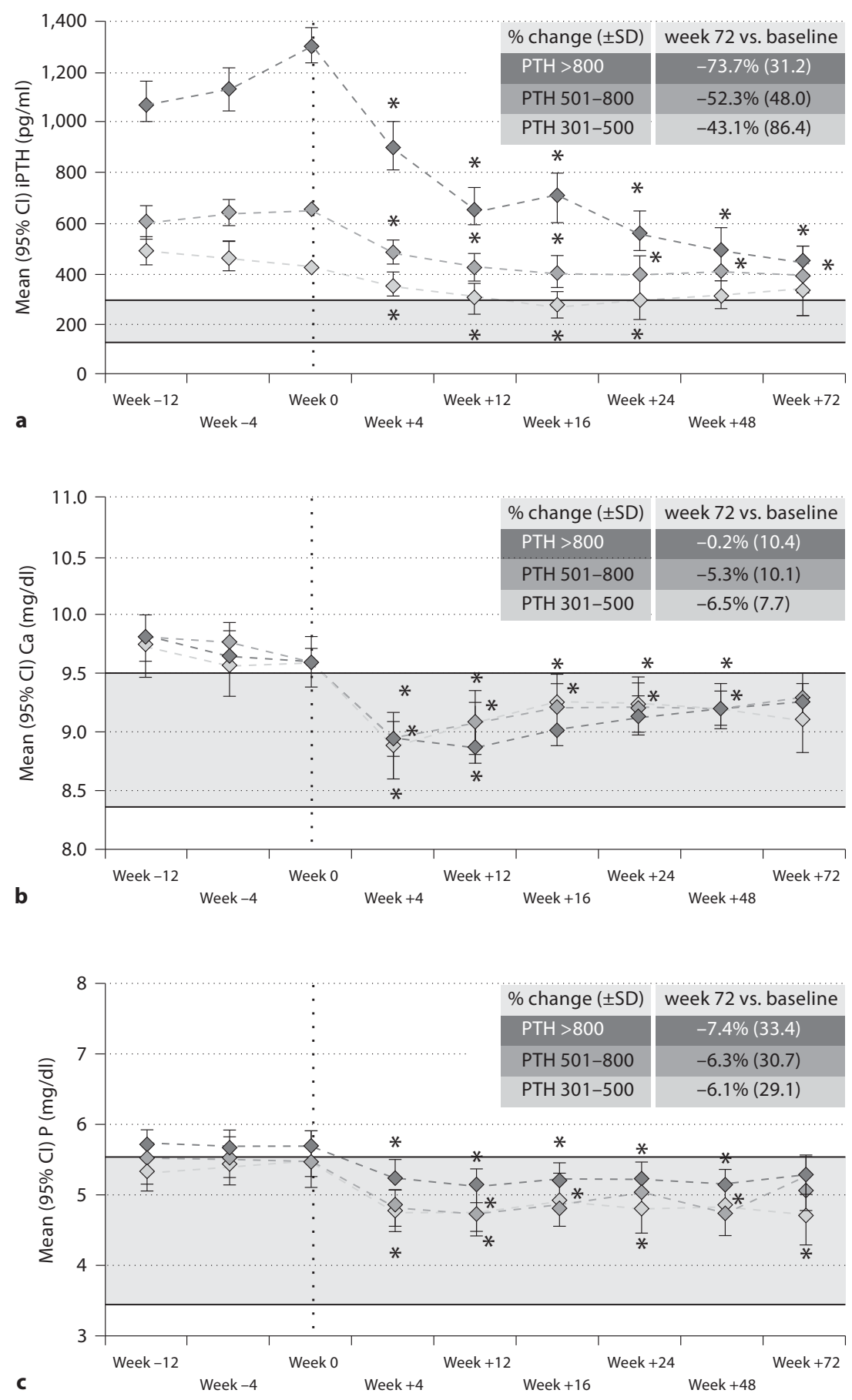

Fig. 3. Changes in mineral metabolism parameters during the study according to baseline SHPT severity. ${ }^{*} \mathrm{p}<0.05$ versus week 0 (baseline); \% change is expressed as median percentage of change. Gray area $=\mathrm{KDOQI}$ targets. 
Fig. 4. Changes in cinacalcet doses during the study.

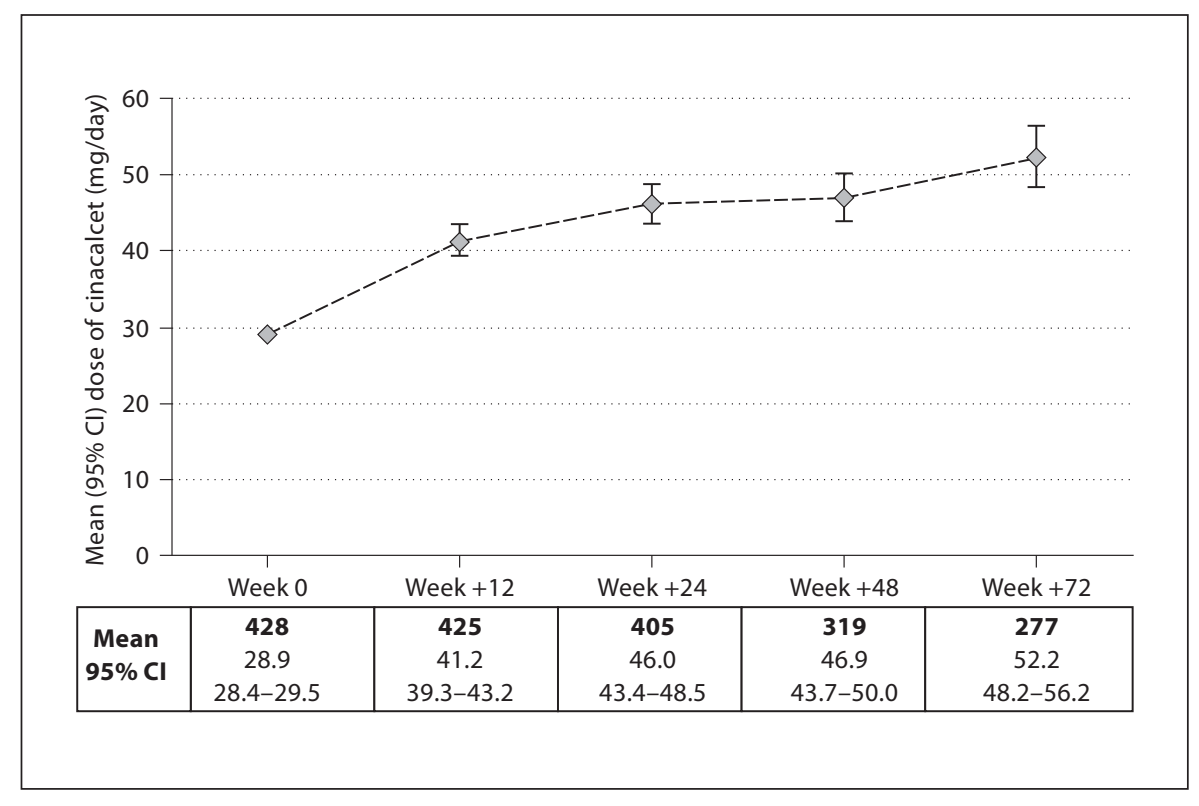

KDOQI Target Achievement

Figure 2 shows the change in $\mathrm{PTH}, \mathrm{Ca}$ and $\mathrm{P}$ levels during follow-up. The proportion of patients within KDOQI targets at baseline and following 72 weeks of cinacalcet was: 0 versus $32.5 \%$ for $\mathrm{iPTH}$ ( $\mathrm{p}<0.05$ ); 40.1 versus $50 \%$ for $\mathrm{Ca}(\mathrm{p}<0.05)$ and 47.7 versus $53.8 \%$ for $\mathrm{P}(\mathrm{p}=0.162)$. The median percentage change in serum iPTH, Ca and $\mathrm{P}$ levels from baseline to week 72 was $-61.7 \%$, i.e. final mean value of $415.6 \pm 349.2 \mathrm{pg} / \mathrm{ml}(44.0 \pm 37.0 \mathrm{pmol} / \mathrm{l})(\mathrm{p}<$ 0.05 vs. baseline); $-3.1 \%$, i.e. $9.3 \pm 0.8 \mathrm{mg} / \mathrm{dl}(2.3 \pm 0.2$ $\mathrm{mmol} / \mathrm{l})(\mathrm{p}<0.05 \mathrm{vs}$. baseline), and $-7.5 \%$, i.e. $5.1 \pm 1.5$ $\pm \mathrm{mg} / \mathrm{dl}(1.6 \pm 0.5 \mathrm{mmol} / \mathrm{l})(\mathrm{p}<0.05 \mathrm{vs}$. baseline), respectively (fig. 2). A total of $73 \%$ of patients had a $\geq 30 \%$ iPTH reduction from baseline or achieved the iPTH target after 72 weeks and $46.9 \%$ of the patients achieved the target of $\mathrm{iPTH} \leq 300 \mathrm{pg} / \mathrm{ml}$ at the end of the study period.

The percentage of patients with iPTH levels $<150 \mathrm{pg} /$ $\mathrm{ml}$ at each follow-up visit was as follows: week $-12,0.9 \%$; week $0,0 \%$ (as required per protocol); week $+24,13.4 \%$; week $+48,11.5 \%$; week $72,11.4 \%$.

\section{Achievement of KDOQI Targets by Initial Severity of SHPT}

During the 72 weeks of follow-up, a significant and sustained decrease in iPTH, Ca and P levels was observed, independently of baseline disease severity (fig. $3 a-c)$. The median reduction in iPTH levels was higher for patients with baseline iPTH $>800 \mathrm{pg} / \mathrm{ml}(-73.7 \pm 31.2 \%, \mathrm{p}<0.05$ vs. baseline) than for patients between 301 and $500 \mathrm{pg} / \mathrm{ml}$
$(-43.1 \pm 86.4 \%, \mathrm{p}=\mathrm{NS})$ or $501-800 \mathrm{pg} / \mathrm{ml}(-52.3 \pm$ $48.0 \%, \mathrm{p}<0.05$ vs. baseline), resulting in similar final levels for the three subgroups.

More patients with baseline iPTH 301-500 pg/ml (63.0\%) completed the study with iPTH levels $<300 \mathrm{pg} /$ $\mathrm{ml}$ with respect to patients with baseline iPTH 501-800 $\mathrm{pg} / \mathrm{ml}(46.3 \%)$ or baseline iPTH $>800 \mathrm{pg} / \mathrm{ml}(43.8 \%)$. However, the percentages of patients achieving KDOQI targets at week 72 were similar for the three severity subgroups $(34.8 \%$ with iPTH $150-300 \mathrm{pg} / \mathrm{ml}$ for patients with baseline iPTH $301-500 \mathrm{pg} / \mathrm{ml} ; 31.3 \%$ for iPTH $501-$ $800 \mathrm{pg} / \mathrm{ml}$ and $33.8 \%$ for iPTH $>800 \mathrm{pg} / \mathrm{ml}$, data not shown for the other parameters).

\section{Cinacalcet and Concomitant Medications during the \\ Study}

Table 2 presents the number of patients treated with each SHPT therapy during the 72 weeks, together with the mean and median administered doses. The cinacalcet dose was significantly increased during the first 12 weeks and continued to increase at a slower rate throughout the study (fig. 4). The dose was increased at least once in $76 \%$ of patients, and decreased at least once in $53 \%$. No changes were performed in $15 \%$ of cases.

Vitamin D sterol use decreased throughout the study ( $p<0.05$ at weeks 24 and 72 vs. baseline; table 2), although the percentage of patients using paricalcitol remained similar. There was a statistically significant increase in the proportion of patients receiving Ca-contain- 
Table 3. Doses of SHPT medications after 72 weeks of cinacalcet treatment in subgroups of patients defined by their baseline SHPT severity

\begin{tabular}{|c|c|c|c|}
\hline & $\begin{array}{l}\text { Baseline iPTH } \\
301-500 \mathrm{pg} / \mathrm{ml} \\
(\mathrm{n}=47)\end{array}$ & $\begin{array}{l}\text { Baseline iPTH } \\
501-800 \mathrm{pg} / \mathrm{ml} \\
(\mathrm{n}=69)\end{array}$ & $\begin{array}{l}\text { Baseline iPTH } \\
>800 \mathrm{pg} / \mathrm{ml} \\
(\mathrm{n}=132)\end{array}$ \\
\hline \multicolumn{4}{|l|}{ Cinacalcet } \\
\hline Patients, $\mathrm{n}$ & $47(100 \%)$ & $69(100 \%)$ & $132(100 \%)$ \\
\hline Mean dose $( \pm S D), \mathrm{mg} /$ day & $44.0 \pm 25.8$ & $51.7 \pm 31.2$ & $57.2 \pm 37.1$ \\
\hline Median dose, mg/day & 34.3 & 45.0 & 60.0 \\
\hline Range, mg/day & $4.3-120$ & $4.3-150$ & $8.57-180$ \\
\hline \multicolumn{4}{|l|}{ Vitamin D sterols } \\
\hline \multicolumn{4}{|l|}{ Oral calcitriol } \\
\hline Patients, $\mathrm{n}$ & $4(9 \%)$ & $6(9 \%)$ & $6(5 \%)$ \\
\hline Mean dose $( \pm S D), \mu g /$ week & $1.4 \pm 0.9$ & $1.4 \pm 0.5$ & $1.2 \pm 0.5$ \\
\hline Median dose, $\mu \mathrm{g} /$ week & 1.1 & 1.5 & 1.5 \\
\hline \multicolumn{4}{|l|}{ Intravenous calcitriol } \\
\hline Patients, $\mathrm{n}$ & 0 & 0 & $10(8 \%)$ \\
\hline Mean dose $( \pm S D), \mu g /$ week & & & $1.9 \pm 1.0$ \\
\hline Median dose, $\mu \mathrm{g} /$ week & & & 1.7 \\
\hline \multicolumn{4}{|l|}{ Intravenous alfacalcidiol } \\
\hline Patients, $\mathrm{n}$ & $6(13 \%)$ & $4(6 \%)$ & $10(8 \%)$ \\
\hline Mean dose $( \pm S D), \mu g /$ week & $2.4 \pm 1.0$ & $3.1 \pm 2.0$ & $4.5 \pm 1.7^{*}$ \\
\hline Median dose, $\mu \mathrm{g} /$ week & 2.6 & 2.5 & 4.0 \\
\hline \multicolumn{4}{|l|}{ Intravenous paricalcitol } \\
\hline Patients, $\mathrm{n}$ & $8(17 \%)$ & $18(26 \%)$ & $23(17 \%)$ \\
\hline Mean dose $( \pm S D), \mu g /$ week & $7.1 \pm 4.7$ & $10.8 \pm 9.8$ & $9.5 \pm 4.0$ \\
\hline Median dose, $\mu \mathrm{g} /$ week & 7.9 & 7.5 & 9.0 \\
\hline \multicolumn{4}{|l|}{ Phosphate binders } \\
\hline \multicolumn{4}{|l|}{ Calcium-based } \\
\hline Patients, $\mathrm{n}$ & $17(36 \%)$ & $34(49 \%)$ & $87(66 \%)^{*}$ \\
\hline Mean dose (SD), mg/day & $2,415 \pm 2,695$ & $1,830 \pm 1,822$ & $2,318 \pm 4,855$ \\
\hline Median dose, mg/day & 1,500 & 1,260 & 1,500 \\
\hline \multicolumn{4}{|l|}{ Sevelamer } \\
\hline Patients, $\mathrm{n}$ & $37(79 \%)$ & $53(77 \%)$ & $94(71 \%)$ \\
\hline Mean dose $( \pm S D), \mathrm{mg} /$ day & $5,276 \pm 2,411$ & $4,906 \pm 2,224$ & $5,004 \pm 2,635$ \\
\hline Median dose, mg/day & 4,800 & 4,800 & 4,800 \\
\hline \multicolumn{4}{|l|}{$\begin{array}{l}\text { Aluminum-based (acetate/ } \\
\text { carbonate) }\end{array}$} \\
\hline Patients, $\mathrm{n}$ & $3(6 \%)$ & $5(7 \%)$ & $21(6 \%)$ \\
\hline Mean dose $( \pm S D), m g /$ day & $1,243 \pm 749$ & $1,445 \pm 797$ & $1,216 \pm 720$ \\
\hline Median dose, mg/day & 932 & 1,864 & 932 \\
\hline
\end{tabular}

ing phosphate binders $(\mathrm{p}<0.05$ at weeks 24 and 72 vs. baseline) and a decrease in the proportion of patients receiving aluminum-based phosphate binders $(\mathrm{p}<0.05$ at week 72 vs. baseline), but the overall use of phosphate binders remained stable. In general, the dose of vitamin D sterols from baseline to 72 weeks slightly decreased; the changes in the dosage of calcitriol (oral and intravenous), alfacalcidiol (intravenous) and paricalcitol (intravenous) were statistically significant. There were no important changes in the dose of phosphate binders throughout the study, except for a slight decrease in the sevelamer dose (table 2).

Despite a similar proportion of patients reaching $\mathrm{iPTH}$ treatment targets in the subgroups defined according to 
Table 4. Adverse reactions to cinacalcet

\begin{tabular}{lll}
\hline Adverse reaction & Patients, $\mathrm{n}$ & Patient, \% \\
\hline Nausea & 23 & 5.4 \\
Dyspepsia & 22 & 5.1 \\
Vomiting & 16 & 3.7 \\
Epigastralgia $_{\text {Hypocalcemia }}$ A $_{\text {Abdominal pain }}$ & 6 & 1.4 \\
Anorexia & 3 & 0.9 \\
Diarrhea & 3 & 0.7 \\
Malaise & 2 & 0.7 \\
Myalgia & 1 & 0.5 \\
Constipation & 1 & 0.2 \\
Lip paresthesia & 1 & 0.2 \\
Gastritis & 1 & 0.2 \\
Pretibial ulcer & 1 & 0.2 \\
\hline
\end{tabular}

${ }^{1}$ According to investigator subjective impression.

initial severity (fig. 3a), the mean dose of cinacalcet at 72 weeks was substantially lower in patients with baseline iPTH $301-500 \mathrm{pg} / \mathrm{ml}(44.0 \mathrm{mg})$ than in patients with baseline iPTH $501-800 \mathrm{pg} / \mathrm{ml}$ or $>800 \mathrm{pg} / \mathrm{ml}$ (51.7 and $57.1 \mathrm{mg}$, respectively) (table 3). The final doses of vitamin $\mathrm{D}$ sterols were also lower in the less severe subgroup (although the percentages of treated patients were similar) whereas there were no differences in the doses of phosphate binders (but a lower number of patients was being treated with Ca-based drugs in the less severe subgroup; table 3).

\section{Treatment Discontinuations, Tolerability and Safety}

Profile

At least $65 \%$ of patients starting cinacalcet in regular clinical practice maintained the treatment after 72 weeks. Forty-three patients (10\%) reported discontinuation of cinacalcet treatment: 5 (1.2\%) due to patient's decision; 6 (1.4\%) due to parathyroidectomy (a low percentage despite of the severe-SHPT population included in the study); in 22 patients (5.1\%), the investigator decided to discontinue the treatment due to efficacy-related reasons ( 1 case due to lack of efficacy and 21 cases due to the investigator's perception of excessive control of SHPT disease), and, finally, in 10 patients (2.3\%), treatment was discontinued due to poor tolerability.

In total, there were 54 patients $(12.6 \%)$ that could be considered as nonresponders to cinacalcet, due to one of the following reasons: parathyroidectomy $(n=6,1.4 \%)$; cinacalcet discontinuation before 72 weeks due to elevated PTH levels $(n=1,0.2 \%)$, or with PTH levels above 300 $\mathrm{pg} / \mathrm{ml}$ or a reduction less than $30 \%$ versus baseline value at 72 weeks ( $\mathrm{n}=47,11.0 \%$, from whom 25 had PTH levels above $800 \mathrm{pg} / \mathrm{ml}$ ).

Table 4 displays the adverse reactions to cinacalcet treatment in 85 patients $(19.9 \%)$. The most common were nausea (5.4\%), dyspepsia (5.1\%) and vomiting (3.7\%). None of them was considered serious, and only in 10 cases $(2.3 \%)$ was treatment discontinuation needed.

\section{Discussion}

Although many data have been collected about cinacalcet in interventional trials, results in large cohorts from routine clinical practice are sparse $[11,12]$. The REHISET study constitutes the first large data collection in Spain on the use and efficacy of cinacalcet in clinical practice. Cinacalcet significantly improved the attainment of KDOQI iPTH, P and Ca targets, simultaneously reducing these parameters in all patients, independent of the degrees of initial SHPT. Thirty-two percent of patients achieved the iPTH target, and an additional 40\% completed the study with more than $30 \%$ reduction of their baseline levels. It is important to note that, despite the described differences between iPTH assays, we replicated the results using validated formulas to convert PTH values to Nichols-equivalent values [15] (the assay on which the KDOQI target was based). In our study, most centers used a second-generation electrochemiluminescence method that does not excessively overestimate $\mathrm{PTH}$, and no significant differences in mean PTH levels or percent of patients achieving the KDOQI target with or without correction to the Nichols values were found (data not shown). The recent 2009 KDIGO guidelines [14], to solve the problem of interassay variability, recommend maintaining iPTH levels in the range of 2-9 times the upper normal limit of each assay, although a recent European publication acknowledges that patients with $\mathrm{iPTH}, \mathrm{Ca}$ and $\mathrm{P}$ levels within the KDOQI target ranges have the lowest risk of mortality compared with those outside the target values and thus, some patients treated following the KDIGO guidelines could be at increased risk of mortality compared with those treated to meet the KDOQI target range [16].

Since the study was conducted soon after cinacalcet commercialization in Spain, the study cohort probably includes patients with more severe forms of SHPT as reflected by their elevated baseline iPTH levels $(940 \mathrm{pg} / \mathrm{ml})$ 
despite administration of classical treatments. Thus, the patients included in the current study were probably those more refractory to vitamin D sterols and phosphate binders, in whom the investigators decided to try the new drug cinacalcet before referring them for parathyroidectomy. This is confirmed by the fact that although the described cohort constitutes $2.3 \%$ of the population undergoing dialysis in Spain in 2005 [17], their demographic and clinical characteristics slightly differ from those prevalent in the overall patients $[17,18]$. Our patients are about 6 years younger, with more women (male:female ratio 1.18 vs. 1.56 for the reference population) and less diabetes (18 vs. $26 \%$ ), although their time on dialysis is similar (median of almost 5 years). It has previously been reported that younger age and absence of diabetes mellitus are associated with more severe SHPT [19]. The differences in these variables could also explain the low mortality rate found in our sample (5.4\% in 72 weeks) compared with the annual mortality of Spanish dialysis patients in that year (13.7\%) [17].

Despite this severity, the efficacy of cinacalcet in this observational study is comparable to that demonstrated in previous clinical trials. At the end of the study, almost one half of the patients (47\%) achieved iPTH levels below $300 \mathrm{pg} / \mathrm{ml}$. This figure is slightly lower than the $56-71 \%$ reported in phase III clinical trials [20-22], and in the OPTIMA [23] and SENSOR [24] studies, but the relative reduction in iPTH levels was a bit higher (62 vs. $48-57 \%$ in the aforementioned studies, which included patients with less severe disease, i.e. baseline iPTH levels between 483 and $840 \mathrm{pg} / \mathrm{ml}$ ). In addition, there were notable differences in the administered doses that must be taken into account. Moe et al. [20,21], in their combined analysis of the 3 placebo-controlled, 26-week, phase III studies with cinacalcet, found that $56 \%$ of the patients had achieved iPTH levels $<300 \mathrm{pg} / \mathrm{ml}$, but the median dose at the end of the studies was $90 \mathrm{mg} /$ day, which is twice as high as the dose we administered ( $45 \mathrm{mg} /$ day). In the 1-year, placebocontrolled trial [22], the doses administered to the entire cinacalcet group were not reported, but the subgroup with $>30 \%$ reduction in the iPTH level (82\%) was receiving a mean of $99 \mathrm{mg} /$ day at the end of the study. Finally, the doses administered in the OPTIMA and SENSOR studies were also higher although more comparable to ours (56 and $67 \mathrm{mg} /$ day in the mean, respectively). The differences are probably due to uptitration of dose per protocol in the aforementioned clinical trials, whereas, in our study, the dose increases were left to the physician's discretion.

The reductions in $\mathrm{Ca}$ and $\mathrm{P}$ were somewhat lower than those reported in 6-month clinical trials [20, 22, 23].
Mean Ca was reduced by $3.1 \%$ in our study versus a mean reduction of $-8,-6.5$ and $-7 \%$ in the studies by Moe et al. [20], Sterrett et al. [22] and Messa et al. [23], respectively. Mean P was reduced by $7.5 \%$ versus $-12 \%$ [20], $-3.6 \%$ [22] and $-10 \%$ [23], respectively.

With regard to other effectiveness data from routine clinical practice, a European study assessing long-term use of cinacalcet (approximately 2,000 patients on dialysis from 12 countries) [11] reported percentages of target achievement very similar to ours. They found that patients with more severe disease were less likely to achieve the iPTH target. In our cohort, similar findings were obtained when only the upper limit of $300 \mathrm{pg} / \mathrm{ml}$ was considered. However, the final percentages of patients meeting the KDOQI target for iPTH in our study did not display significant differences according to baseline severity due to a higher number of individuals with less severe disease whose iPTH levels fell below $150 \mathrm{pg} / \mathrm{ml}$. The mean cinacalcet doses in the ECHO study were comparable (58-62 mg/day for patients with baseline iPTH 721$1,050 \mathrm{pg} / \mathrm{ml}$ and $>1,050 \mathrm{pg} / \mathrm{ml}$, respectively). As our results suggest that long-term dialysis predicts poor response to cinacalcet, the longer disease duration reported for their patients (mean of more than 6.5 years) might explain the differences between the two studies. Concerning low levels of PTH, although epidemiologic studies have been conducted on patients with SHPT mainly treated with vitamin $\mathrm{D}$ derivatives, and the significance of PTH values may not be the same in a cohort using calcimimetics, they should be avoided in dialysis patients $[13,14,16]$. Thus, Ca-containing phosphate binders, vitamin $\mathrm{D}$ derivatives and/or calcimimetics should be reduced or stopped [14].

In a large USA cohort treated with cinacalcet over 12 months [12], St. Peter et al. found worse results than those reported here, with only one quarter of patients achieving the iPTH target (from a median baseline PTH level of 577 $\mathrm{pg} / \mathrm{ml}$ ). Although the differences in response cannot be readily explained, their population presented important differences such as younger age and a larger number of African-American patients, but on the other hand, they were less time on dialysis and included a higher proportion of diabetics. The dose at 12 months for those patients (55 mg) was very similar to ours, with higher use of vitamin D sterols.

As expected, the mean cinacalcet dose increased according to disease severity, with $29 \%$ higher dose requirements in patients with severe disease. The final median dose in this subgroup was $60 \mathrm{mg} / \mathrm{day}$, which suggests that cinacalcet was uptitrated - although very slowly - in the 
patients with severe disease. Further studies should address the question whether the effectiveness could be improved with the use of higher doses, within the technical specifications (maximum recommended dose of $180 \mathrm{mg} /$ day). Pharmacokinetic data suggest that dose response is linear over the range of $25-200 \mathrm{mg}$ /day in patients on hemodialysis, and that gastrointestinal effects may be dose related [25]. In our study, treatment with cinacalcet was generally well tolerated. Dyspepsia, nausea or vomiting appeared in about $5 \%$ of patients, but led to treatment discontinuation in very few cases. These incidences are slightly lower to those reported in clinical trials [20-24, 26] (nausea: $13-32 \%$, vomiting: 9-27\%). A possible explanation could be the longer titration period in our study, but we cannot discard an underestimation of the incidence of adverse events due to the retrospective design, which is not a good way to assess tolerability. There is a probable association between the incidence of adverse events and the cinacalcet dose, but some degree of individual susceptibility also seems to be involved [20-24].

The use of cinacalcet was accompanied by a reduction in the use of vitamin D sterols, although the percentage of patients using paricalcitol remained similar. It must be noted that the number of patients on vitamin $\mathrm{D}$ treatment at baseline was particularly low for a SHPT cohort (less than $40 \%$ ). A possible explanation could be that high Ca and/or P levels militated against the use of vitamin D sterols. After the introduction of cinacalcet, which allowed a better control of both $\mathrm{Ca}$ and $\mathrm{P}$, we did not observe an increased use of vitamin D sterols, not even at low doses. Block et al. [27], in a clinical trial of combined therapy with cinacalcet and low doses of vitamin D sterols, found that $62 \%$ of patients refractory to conventional therapy achieved the KDOQI iPTH target in parallel with a reduction of $51 \%$ in the weekly dose of vitamin D sterols. However, it is important to emphasize that due to the increasingly recognized benefits of vitamin $\mathrm{D}$ in dialysis patients [28], nephrologists should be aware that the use of cinacalcet (probably irrespective of PTH levels) should not preclude the addition of native vitamin $\mathrm{D}$ (with pleiotropic effects beyond mineral metabolism, as recently demonstrated by Matias et al. [29]). As mentioned before, others have found an increased and more consistent use of vitamin $\mathrm{D}$ [12]. Thus, cinacalcet may allow treatment optimization with native or active vitamin $\mathrm{D}$ compounds.

Reductions in the use of some phosphate binders (especially sevelamer) [30] have also been described, although we did not observe such a trend. On the other hand, a significant increase in patients taking Ca-based phosphate binders is confirmed. It is important to em- phasize that Ca-based phosphate binders have been associated with an increased risk of progression of vascular calcification before the calcimimetic era [31], and that they may have contributed to oversuppression of PTH in some patients. Results of prospective studies that are being currently conducted will allow more information to be gained in this relevant issue.

Almost $20 \%$ of the patients were on aluminium-based phosphate binders at baseline. Although they are not recommended for long-term use either by International or Spanish guidelines, a significant percentage of patients are still receiving them in routine practice $[32,33]$.

Our study included a large number of patients with a long follow-up, thus providing evidence from use of cinacalcet in routine clinical practice, in contrast to previous clinical trials. Nevertheless, there are certain limitations inherent in observational studies that should be taken into account. The included population was not entirely representative of the overall SHPT population, as they were refractory to conventional treatments. We collected data on concomitant medication use, but did not have enough patients to evaluate the effectiveness in each drug combination. For this reason, we cannot exclude that the effect of cinacalcet may differ depending on the use of concomitant agents, but previous stratified analyses from clinical and observational trials suggest that this effect is low $[27,34]$. We did not control for other potential confounders as comorbidities or compliance with administered medications, which could influence the amount of delivered dose and drug effectiveness. As there was no comparator group, it is not clear whether our findings may be attributed only to cinacalcet. However, during the 12 weeks before the initiation of cinacalcet the iPTH levels of this cohort were rising despite classical treatment. Further studies assessing dose adjustments performed in clinical practice in more detail could help establishing maximal benefits of cinalcalcet depending on patients' profiles (baseline severity, concomitant medications, age, time on dialysis).

Despite the improvement in biochemical parameters observed in the current and previous studies, the effect of cinacalcet on patient outcomes needs to be verified. Some combined analyses of clinical trials [35] suggest that cinacalcet is associated with significant reductions in the risk of parathyroidectomy, fracture and cardiovascular hospitalization; ongoing clinical trials have been specifically designed to answer those questions [36, 37].

In conclusion, cinacalcet in routine clinical practice allows increasing the percentage of patients achieving the treatment targets for iPTH, Ca and P, regardless of SHPT 
disease severity at treatment initiation, simultaneously reducing all three laboratory parameters, and maintaining its effectiveness over a 72 -week period. It must be stressed that the observed biochemical benefits were obtained with doses of cinacalcet $50 \%$ lower than those used in phase III studies. The optimal use of phosphate-binders and vitamin D in cinacalcet-treated patients needs to be addressed in future studies.

\section{Acknowledgements}

This study was supported in part by a grant from Amgen, S.A. Writing assistance was supported by Neus Valveny from Trial Form Support. The authors wish to thank all the participating REHISET Study investigators and centers: Enric Andres Ribes (Fundacio Puigvert + Clínica Renal Tefnut + Centre de Diálisis Bonanova + C. Diálisis Julio Verne); Alejandro Martín Malo (Hospital Reina Sofia, Córdoba); $\mathrm{M}^{\mathrm{a}}$ Asunción Galicia Basart (Hospital del Valle Hebron); Clotilde Rios Camacho (Hospital Virgen de La Macarena); $M^{a}$ Carmen Sánchez Perales (Hospital General de Jaen); Francisco Coronel (Hospital Clínico San Carlos + ICN Moncloa); Higinio Cao Baduell (Hospital del Mar); Alberto Martínez Castelao (Hospital de Bellvitge); Amparo Bernat García (Nefroclub-Hospital Dr. Peset); Dolores Arenas Jiménez (Sanatorio Perpetuo Socorro); Rafa Díaz-Tejeiro Izquierdo (Hos- pital Virgen de La Salud); Antonio Molina (Hospital Río Hortega); Jesús Olivares Martín (Hospital General de Alicante); Ángel Luis Martín de Francisco (Hospital Marqués de Valdecilla ); Aurora Lopez Montes (Hospital General de Albacete); Ángel Garbayo Chivite (Hospital Miguel Servet); $M^{a}$ Del Mar Castilla Castellano (Hospital Costa del Sol ); Jesús Bustamante Bustamente (Hospital Clínico de Valladolid); José María Graña Fandos (Hospital de La Ribera); Francisco Javier Moncalian León (Complejo Hospitalario Juan Canalejo); Guillermo Martín Reyes (Hospital Carlos Haya); Joan Feixas Roma (Hospital General de Vic); Enrique Vicente Albert Balaguer (Centro de Diálisis Valencia Cedival - Hospital Dr. Peset); Emilio Gonzalez Parra (Hospital de Medina del Campo); Marisa Alcalá Rueda (Centros De Diálisis-Hospital de Jerez); Gloria Martin (Institut Hemodialysis Barcelona), Rafael Pérez Mijares Pérez (Hospital de Jerez); Julián García De Diego/ César González Martínez (Hospital de Elche); Andrés Antolín Cariñena (Centro de Diálisis Cediat-Aldaia - Hospital General U. De Valencia); Domingo Sánchez-Guisande Jack (Complexo Universitario Santiago-Conxo); Víctor Lorenzo (Hospital C.U. de Canarias); Jorge Reichert (Centro de Diálisis Renal Kidney-Valladolid); Marta Luzón (Hospital Miguel Servet); Carlos Santiago (Hospital General de Alicante).

\section{Conflict of Interest}

This study was supported in part by a grant from Amgen, SA.

\section{References}

1 Owda A, Elhwairis H, Narra S, Towery H, Osama S: Secondary hyperparathyroidism in chronic hemodialysis patients: prevalence and race. Ren Fail 2003;25:595-602.

-2 Slatopolsky E, Brown A, Dusso A: Pathogenesis of secondary hyperparathyroidism. Kidney Int Suppl 1999;73:S14-S19.

-3 Ganesh SK, Stack AG, Levin NW, HulbertShearon T, Port FK: Association of elevated serum $\mathrm{PO}_{4}, \mathrm{Ca} \times \mathrm{PO}_{4}$ product, and parathyroid hormone with cardiac mortality risk in chronic hemodialysis patients. J Am Soc Nephrol 2001;12:2131-2138.

4 National Kidney Foundation: K/DOQI clinical practice guidelines for bone metabolism and disease in chronic kidney disease. Am J Kidney Dis 2003;42(suppl 3):S1-S201.

5 Block GA, Port FK: Re-evaluation of risks associated with hyperphosphatemia and hyperparathyroidism in dialysis patients: recommendations for a change in management. Am J Kidney Dis 2000;35:1226-1237.

6 Nemeth EF, Steffey ME, Hammerland LG, Hung BC, Van Wagenen BC, DelMar EG, Balandrin MF: Calcimimetics with potent and selective activity on the parathyroid calcium receptor. Proc Natl Acad Sci USA 1998; 95:4040-4045.

7 Fox J, Lowe SH, Conklin RL, Nemeth EF: The calcimimetic NPS R-568 decreases plas- ma PTH in rats with mild and severe renal or dietary secondary hyperparathyroidism. Endocrine 1999;10:97-103.

8 Silver J, Naveh-Many T: Phosphate and the parathyroid. Kidney Int 2009;75:898-905.

-9 Block GA, Martin KJ, de Francisco AL, Turner SA, Avram MM, Suranyi MG, Hercz G, Cunningham J, Abu-Alfa AK, Messa P, Coyne DW, Locatelli F, Cohen RM, Evenepoel P, Moe SM, Fournier A, Braun J, McCary LC, Zani VJ, Olson KA, Drüeke TB, Goodman WG: Cinacalcet for secondary hyperparathyroidism in patients receiving hemodialysis. N Engl J Med 2004;350:1516-1525.

10 Lindberg JS, Culleton B, Wong G, Borah MF, Clark RV, Shapiro WB, Roger SD, Husserl FE, Klassen PS, Guo MD, Albizem MB, Coburn JW: Cinacalcet $\mathrm{HCl}$, an oral calcimimetic agent for the treatment of secondary hyperparathyroidism in hemodialysis and peritoneal dialysis: a randomized, doubleblind, multicenter study. J Am Soc Nephrol 2005; $16: 800-807$

11 Ureña P, Jacobson SH, Zitt E, Vervloet M, Malberti F, Ashman N, Leavey S, Rix M, Os I, Saha H, Ryba M, Bencova V, Baños A, Zani V, Fouque D: Cinacalcet and achievement of the NKF/K-DOQITM recommended target values for bone and mineral metabolism in real-world clinical practice - the ECHO ob- servational study. Nephrol Dial Transplant 2009;24:2852-2859.

12 St Peter WL, Li Q, Liu J, Persky M, Nieman $\mathrm{K}$, Arko C, Block GA: Cinacalcet use patterns and effect on laboratory values and other medications in a large dialysis organization, 2004 through 2006. Clin J Am Soc Nephrol 2009;4:354-360.

13 Torregrosa JV, Cannata Andia J, Bover J, Caravaca F, Lorenzo V, Martín de Francisco AL, Martín-Malo A, Martínez I, González Parra E, Fernández Giráldez E, Rodríguez Portillo M; Sociedad Española de Nefrologia: Guias SEN: Recomendaciones de la Sociedad Espanola de Nefrología para el manejo de las alteraciones del metabolismo oseo-mineral en los pacientes con enfermedad renal crónica. Nefrologia 2008;28(suppl 1):1-22.

14 Kidney Disease: Improving Global Outcomes (KDIGO) CKD-MBD Work Group. KDIGO clinical practice guideline for the diagnosis, evaluation, prevention, and treatment of chronic kidney disease-mineral and bone disorder (CKD-MBD). Kidney Int Suppl 2009;(113):S1-S130.

15 de la Piedra C, Fernández E, González Casaus ML, González Parra E: Diferencias en la función de los péptidos paratiroideos. ¿Qué estamos midiendo? Nefrología 2008;28:123128. 
16 Floege J, Kim J, Ireland E, Chazot C, Drueke T, de Francisco A, Kronenberg F, Marcelli D, Passlick-Deetjen J, Schernthaner G, Fouqueray $\mathrm{B}$, Wheeler DC; on behalf of the ARO Investigators: Serum iPTH, calcium and phosphate, and the risk of mortality in a European haemodialysis population. Nephrol Dial Transplant. 2010:Apr 25. Epub ahead of print.

17 Sociedad Española de Nefrología-Grupo de Registros de Enfermos Renales: Diálisis y Trasplante 2006 (Informe preliminar). http://www.senefro.org/modules/subsection/files/informe_registro_enfermos renales_2006.pdf?check_idfile $=2923$. Accessed on April, 7th, 2009.

-18 Alcázar JM, Arenas MD, Alvarez-Ude F, Virto R, Rubio E, Maduell F, Fernández-Crespo P, Angoso de Guzmán M, Ramón Delgado R, Santamaría C, Alonso MA, Anaya S, Bordils A, Antolín A, Gonzalez-Parra E, Pérez I, Molina Ordás A, Fernández M, Molina P, Sánchez P, Barbosa F, Palomares Solla L, Lacueva J, Barril G, Pastor JM, Gámez Matías C, Mateos Hernández P, Fulquet Nicolas M, Ríos F, Rebollo P, Parra E: Resultados del proyecto de mejora de la calidad de la asistencia en hemodiálisis: estudio multicéntrico de indicadores de calidad de la Sociedad Española de Nefrología (SEN). Nefrologia 2008;28:597-606.

-19 Avram MM, Mittman N, Myint MM, Fein P: Importance of low serum intact parathyroid hormone as a predictor of mortality in hemodialysis and peritoneal dialysis patients: 14 years of prospective observation. Am J Kidney Dis 2001;38:1351-1357.

-20 Moe SM, Chertow GM, Coburn JW, Quarles LD, Goodman WG, Block GA, Drüeke TB, Cunningham J, Sherrard DJ, McCary LC, Olson KA, Turner SA, Martin KJ: Achieving NKF-K/DOQI bone metabolism and disease treatment goals with cinacalcet $\mathrm{HCl}$. Kidney Int 2005;67:760-771.

21 EPARs for authorized medicinal products for human use. http://www.emea.europa.eu/ humandocs/Humans/EPAR/mimpara/ mimpara.htm.
22 Sterrett JR, Strom J, Stummvoll HK, Bahner U, Disney A, Soroka SD, Corpier C, Arruda JA, Schwanauer LE, Klassen PS, Olson KA, Block GA: Cinacalcet HCl (Sensipar/Mimpara) is an effective chronic therapy for hemodialysis patients with secondary hyperparathyroidism. Clin Nephrol 2007;68: $10-17$.

-23 Messa P, Macário F, Yaqoob M, Bouman K, Braun J, von Albertini B, Brink H, Maduell F, Graf H, Frazão JM, Bos WJ, Torregrosa V, Saha H, Reichel H, Wilkie M, Zani VJ, Molemans B, Carter D, Locatelli F: The OPTIMA study: assessing a new cinacalcet (Sensipar/ Mimpara) treatment algorithm for secondary hyperparathyroidism. Clin J Am Soc Nephrol 2008;3:36-45.

24 Schaefer RM, Bover J, Dellanna F, Sanz D, Asensio C, Sánchez González MC, Gross P, Zani V, Carter D, Jehle PM: Efficacy of cinacalcet administered with the first meal after dialysis: the SENSOR Study. Clin Nephrol 2008;70:126-134.

-25 Padhi D, Harris RZ, Salfi M, Noveck RJ, Sullivan JT: Pharmacokinetics and pharmacodynamics of cinacalcet in hepatic impairment: phase I, open-label, parallel-group, single-dose, single-centre study. Clin Drug Investig 2008;28:635-643.

26 Strippoli GF, Tong A, Palmer SC, Elder G Craig JC: Calcimimetics for secondary hyperparathyroidism in chronic kidney disease patients. Cochrane Database Syst Rev 2006;18(4): CD006254 Review.

27 Block GA, Zeig S, Sugihara J, Chertow GM, Chi EM, Turner SA, Bushinsky DA: Combined therapy with cinacalcet and low doses of vitamin $\mathrm{D}$ sterols in patients with moderate to severe secondary hyperparathyroidism. Nephrol Dial Transplant 2008;23:23112318

28 Andress DL: Vitamin D in chronic kidney disease: a systemic role for selective vitamin D receptor activation. Kidney Int 2006;69: 33-43.

29 Matias PJ, Jorge C, Ferreira C, Borges M, Aires I, Amaral T, Gil C, Cortez J, Ferreira A Cholecalciferol supplementation in hemodialysis patients: effects on mineral metabolism, inflammation, and cardiac dimension parameters. Clin J Am Soc Nephrol 2010;5: 905-911.
30 Arenas MD, Rebollo P, Alvarez-Ude F, Prieto L, Gil MT, Malek T, Moledous A, Núñez C: Es el cinacalcet un tratamiento coste-efectivo en el hiperparatiroidismo secundario severo en pacientes en hemodialisis? Nefrologia 2008;28:511-516.

- 31 Chertow GM, Burke SK, Raggi P; Treat to Goal Working Group: Sevelamer attenuates the progression of coronary and aortic calcification in hemodialysis patients. Kidney Int 2002;62:245-252.

32 Arenas MD, Alvarez-Ude F, Gil MT, Soriano A, Egea JJ, Millán I, Amoedo ML, Muray S, Carretón MA: Application of NKF-K/DOQI Clinical Practice Guidelines for Bone Metabolism and Disease: changes of clinical practices and their effects on outcomes and quality standards in three haemodialysis units. Nephrol Dial Transplant 2006;21: 1663-1668.

33 Lorenzo V, Martin-Malo A, Perez-Garcia R, Torregrosa JV, Vega N, de Francisco AL, Cases A: Prevalence, clinical correlates and therapy cost of mineral abnormalities among haemodialysis patients: a cross-sectional multicentre study. Nephrol Dial Transplant 2006;21:459-465.

34 Ashman N, Fouque D, Baños A, Harris C, Stefan H, Jacobson on Behalf of the Pan-European ECHO Study Investigator Group: The ECHO Study: The use of cinacalcet (Mimpara ${ }^{\circledR} /$ Sensipar ${ }^{\circledR}$ ) in patients receiving/not receiving vitamin $D$ in clinical practice (Abstract). ERA-EDTA, Stockholm, May 2008.

-35 Cunningham J, Danese M, Olson K, Klassen P, Chertow GM: Effects of the calcimimetic cinacalcet $\mathrm{HCl}$ on cardiovascular disease, fracture, and health-related quality of life in secondary hyperparathyroidism. Kidney Int 2005;68:1793-1800.

36 http://clinicaltrials.gov/ct2/show/NCT0037 9899? term $=$ cinacalcet\&rank $=2$

37 Chertow GM, Pupim LB, Block GA, CorreaRotter R, Drueke TB, Floege J, Goodman WG, London GM, Mahaffey KW, Moe SM, Wheeler DC, Albizem M, Olson K, Klassen P, Parfrey P: Evaluation of cinacalcet therapy to lower cardiovascular events (EVOLVE): rationale and design overview. Clin J Am Soc Nephrol 2007;2:898-905. 